\title{
POST PARTUM DEPRESSION AMONG WOMEN ATTENDING MATERNAL AND CHILD HEALTH CLINIC IN SELECTED HOSPITALS OF NEPAL
}

Mishra $D^{1 \dagger}$, Shakya DV ${ }^{2}$, Pathak RS², Mishra $\mathrm{S}^{3}$

${ }^{1}$ Department of Public Health, Manmohan Memorial Institute of Health Sciences, Soalteemode, Kathmandu

${ }^{2}$ Central Department of Population Studies, Tribhuvan University, Kirtipur, Kathmandu

${ }^{3}$ Center for Mental Health and Counseling, Thapathali Height Kathmandu

†Corresponding author: Durga Mishra Associate Professor Email; durgamk07@gmail.com ABSTRACT

Background: The postpartum non-psychotic depression is one of the most common complications of childbearing affecting about $10-15 \%$ of women and is representative prevalence to consider as a public health problem affecting women and their families. The major objectives of this study were to assess magnitude of postpartum depression and to identify possible reasons.

Methods: Mixed method was adopted for the study. Individual interview questionnaire and Nepali version Edinburgh Postnatal Depression Scale (EPDS) were used as quantitative tool among 260 women attending MCH clinic for vaccinating their children under the age of one from purposively selected three Tarai hospitals in Nepal. 248 respondents were included in the analysis. For the qualitative part, Focus Group Discussion (FGD), In-depth interview (IDI) and Key Informants Interview (KII) were used. Data analysis was done using SPSS (20). Chi-square test was done to show strength of association. Theme building was done for qualitative analysis. Findings from both studies have been triangulated.

Results: Among the 248 respondents 177 (71.4\%) of them showed no signs of depression however, in the 71 (28.6\%) respondents the postpartum depression was found through EPDS. The prevalence of postpartum depression was seen in all kinds of socio- economic and demographic characteristics but varied in the magnitude. 
Conclusions: Women from anywhere can be sufferers of the post partum depression and the findings of this study would be an important evidence for an individual, family, community and policy makers and programme designers/implementers in managing this problem properly.

Keywords: MCH clinic; postpartum depression; selected hospital; women.

\section{INTRODUCTION}

The postpartum depression (PPD) is the most common complication of childbearing women (10$15 \%$ ) to consider as a public health problem. It has multi-faced effects. ${ }^{1-6}$. This condition begins within the first six weeks of postpartum and require treatment. The signs and symptoms include depressed mood, unhappiness and low energy. Suicidal ideation is also common. ${ }^{7}$. Once women are suffered from PPD are twice as likely to experience future episodes, over a 5-year children are particularly vulnerable.”. The cause of depression can be multi-factorial ". ${ }^{8}$. Only 57\% of received a PNC could be the appropriate time for identifying physical as well as mental health problems but many women are unable to receive such services. ${ }^{9}$ Many studies done in other countries and in Nepal such studies are nominal in particular area with low status of women.

The main purpose of this study was to assess the prevalence of PPD and its possible reasons.

\section{Methods}

\section{Study Design and data collection tools}

A Mixed method study design was adopted. Edinburg Postnatal Depression Scale (EDPS) and Pfizar Patient Health Questionnaire (PHQ -9) was used for collecting quantitative data and for the qualitative study, in-depth interview, Focused Group Discussion and key informants interview techniques and guidelines were used.

Validation studies have utilized various threshold scores in EPDS determining which women were positive and in need of referral. Cut-off scores range from 9 to 13 points. A woman scoring 9 or more points or indicating any suicidal ideation - that is, she scores 1 or higher on question number 10 - should be referred immediately for follow-up. ${ }^{10}$

\section{Study Site}


In total 3 hospitals including Bharatpur, Lumbini Zonal Hospital and Narayani Sub-Regional Hospital located in Tarai area were selected purposively. The MCH Clinics of the hospitals where post natal mothers were coming for the routine immunization to their children and District Public Health Offices of respective districts were the study sites for this study.

\section{Study Population}

Women of reproductive age (15- 45 years) specifically postnatal mothers from 1 - 12 months after delivery were the study population and unit for quantitative (cross-sectional descriptive) study and for the qualitative study women of same age group attending for child immunization and relevant key stakeholders were taken.

For the Key Informants Interview (KII), Public Health Nurses of District Public Health Offices, Medical Director and Nursing Directors, departmental in-charges were interviewed.

\section{Sample size}

Total 260 samples (Bharatpur: 96, Lumbini Zonal Hospital: 86, Narayani Sub-Regional hospital: 78 ) were collected. In each site of the study, two round of data collection was done during the immunization days. There were 12 incomplete questionnaires omitted and 248 analyzed.

\section{Ethical Consideration}

Ethical approval was taken from Institutional Review Committee of Manmohan Memorial Institute of Health Sciences. The strengths and limitations of each technique and tools of the data collection have been taken into considerations.

\section{Data Analysis}

Data analysis was done in the software, (SPSS 20.0). All the outputs were tabulated in tabular forms with simple frequency and percentage. To measure the PPD among women attending $\mathrm{MCH}$ clinic, the specific criteria mentioned in the EPDS were applied (cited from Murray et al., 1990) ${ }^{11}$. Here from 0 to 9 scores were considered as no depression and above 10 was considered as depression. Descriptive statistics were applied to socio-demographic, medical and obstetric 
variables. Chi-square $\left(\chi^{2}\right)$ test with Fisher's exact 2 sided significant values were applied to the study variables.

Breaking, connecting, summarizing, synthesizing, interpretation and presenting the discoveries have been done for qualitative study. Other relevant matters and findings from the similar types of studies have also been adopted and triangulated. For the analysis of qualitative data, organized the responses from three FGD, three in-depth interview and eight key informants.

The women for IDI were selected as follow up case to those women who had shown some depressive behaviors during the individual interview and expressed seeking of some sorts of supports from the medical person. Among the three IDI, the first was done in Chitwan and two in Rupandehi. Both structured and semi-structured questionnaires were used and analysis was done.

\section{RESULTS}

Among the 248 respondents, 177 (71.4\%) of them have no depression and 71 (28.6\%) having postpartum depression (Table 1).

Among 71 having depression ,the highest $17 \%$ of were from age group of 20-24 years ,6 \% from 25- 29 years and 40 years and above were $1 \%$. There is not significant association found $(0.732$ p-values).

PPD, highest $13 \%$ found in Janajati , 7 \%, Muslims , 5\% Brahmins , 3\% Chhetris and Dalits 1\%. There is near to significant association between the ethnicity and PPD (0.066).

The highest 19\% were Hindus by religion followed by $9 \%$ Muslims and less than 1\% Buddhists and Christians. There is significant relationship observed with 0.016 values (Table 2).

Within all types of occupation $26 \%$ were household, 2 \% were business,formal job/service had less than $1 \%$ of PPD. There is no significant association found with $0.678 \mathrm{p}$ - value.

Percentage within the educational level of the respondents the highest $7 \%$ was found in illiterate group. There is strong association found value as 0.014 . 
The main source of income reveals that PPD is found to be highest among the income from salary $13 \%$, business $6 \%$, wages $5 \%$, agriculture $4 \%$ and less than $1 \%$ in animal husbandry . There is no significant association found with 0.364 values (Table 3).

Those whose income is sufficient for 3 months have had the highest, 14.1\% of PPD and sufficient income for 12 months $12 \%$, sufficient for 6 months have had $3 \%$. There is no association found as 0.115 values.

Whose husband having higher secondary level of education have had highest PPD with 7 \%, literate $5 \%$, secondary $5 \%$, illiterate $4 \%$ and $3 \%$ among completed primary level. There is nearly significant association found with 0.006 values.

Whose husbands having labor work have had the highest 11\%, business $9 \%$ and formal job/service 8\% of PPD. Very few foreign employment and no one case from other. There is not significant association fund by 0.669 values.

Respondents having PPD the highest 14\% who moved alone followed by those accompanied by the seniors $13 \%$, it is very less among accompanied by juniors $1 \%$. There is not significant association observed with the value of 0.085 (Table 4).

The prevalence of PPD is highest, $25 \%$, in those who have no history of any health problems and $4 \%$ having that. There is not significant association observed with 0.143 .

From the total PPD, the highest $12 \%$ in respondents with two pregnancies, $11 \%$ in the first time and rests are third to sixth. There is not significant association observed as 0.195 values.

Those who have none, one or two male children have 15\%, $7 \%$ and $6 \%$ PPD respectively. There is significant found as 0.043 values.

Among the total PPD, 18\% of respondent have the male baby and 11\% have female recently. There is association found as 0.049 values (Table 5).

Among the total PPD, 27\% of those who have had institutional deliveries where as less than $2 \%$ in home delivery. There is no association found as 1.000 values. 


\section{Original Article}

PPD is a higher $25 \%$ among the normal vaginal deliveries where as $3 \%$ in the caesarian section. No significant association found with 0.429 values (Table 6).

Table 1: Prevalence of depression among the respondents according to EPDS

\begin{tabular}{|l|l|l|}
\hline Depression & Number & Percent \\
\hline No depression & 177 & 71.4 \\
\hline Depression & 71 & 28.6 \\
\hline Total & $\mathbf{2 4 8}$ & $\mathbf{1 0 0 . 0}$ \\
\hline
\end{tabular}

\begin{tabular}{|c|c|c|c|c|c|c|}
\hline \multirow{2}{*}{$\begin{array}{l}\text { Age Group } \\
\text { and } \\
\text { postpartum } \\
\text { depression }\end{array}$} & \multicolumn{2}{|c|}{ No Depression } & \multicolumn{2}{|c|}{ Depression } & \multirow{2}{*}{$\begin{array}{l}\text { Exact } \\
\text { Sig. (2- } \\
\text { sided) }\end{array}$} & \multirow[b]{2}{*}{ Remarks } \\
\hline & Number & $\begin{array}{ll}\% & \text { of } \\
\text { total } & \end{array}$ & Number & \% of Total & & \\
\hline 15-19 years & 18 & $7.3 \%$ & 8 & $3.2 \%$ & \multirow{6}{*}{.732} & \multirow{6}{*}{$\begin{array}{l}\text { Not } \\
\text { significant }\end{array}$} \\
\hline 20-24 years & 94 & $37.9 \%$ & 43 & $17.3 \%$ & & \\
\hline 25-29 years & 42 & $16.9 \%$ & 14 & $5.6 \%$ & & \\
\hline 30-34 years & 17 & $6.9 \%$ & 4 & $1.6 \%$ & & \\
\hline 40 years above & 5 & $2.0 \%$ & 1 & $.4 \%$ & & \\
\hline Total & 177 & $71.4 \%$ & 71 & $28.6 \%$ & & \\
\hline \multicolumn{7}{|c|}{ Ethnicity and depression } \\
\hline Brahmin & 42 & $16.9 \%$ & 13 & $5.2 \%$ & \multirow{6}{*}{.066} & \multirow{6}{*}{$\begin{array}{l}\text { Near to } \\
\text { significant }\end{array}$} \\
\hline Chhetri & 21 & $8.5 \%$ & 7 & $2.8 \%$ & & \\
\hline Janajati & 66 & $26.6 \%$ & 31 & $12.5 \%$ & & \\
\hline Dalit & 24 & $9.7 \%$ & 3 & $1.2 \%$ & & \\
\hline Muslim & 24 & $9.7 \%$ & 17 & $6.9 \%$ & & \\
\hline Total & 177 & $71.4 \%$ & 71 & $28.6 \%$ & & \\
\hline
\end{tabular}




\section{Original Article}

\begin{tabular}{|c|c|c|c|c|c|c|}
\hline \multicolumn{7}{|c|}{ Religion and depression } \\
\hline Hindu & 142 & $57.3 \%$ & 47 & $19.0 \%$ & \multirow{6}{*}{.016} & \multirow{6}{*}{ Significant } \\
\hline Buddhist & 7 & $2.8 \%$ & 1 & $.4 \%$ & & \\
\hline Muslim & 27 & $10.9 \%$ & 21 & $8.5 \%$ & & \\
\hline Christian & 1 & $.4 \%$ & 1 & $.4 \%$ & & \\
\hline Others & 0 & $0.0 \%$ & 1 & $.4 \%$ & & \\
\hline Total & 177 & $71.4 \%$ & 71 & $28.6 \%$ & & \\
\hline
\end{tabular}

Table:3 Prevalence of postpartum depression according to socio-economic status of the respondents $(n=248)$

\begin{tabular}{|c|c|c|c|c|c|c|}
\hline \multirow{2}{*}{$\begin{array}{l}\text { Occupation } \\
\text { postpartum } \\
\text { depression }\end{array}$} & \multicolumn{2}{|c|}{ No Depression } & \multicolumn{2}{|c|}{ Depression } & \multirow{2}{*}{$\begin{array}{l}\text { Exact } \\
\text { Sig. (2- } \\
\text { sided) }\end{array}$} & \multirow[b]{2}{*}{ Remarks } \\
\hline & Number & $\begin{array}{l}\text { \% of } \\
\text { Total }\end{array}$ & Number & $\begin{array}{ll}\% & \text { of } \\
\text { Total } & \end{array}$ & & \\
\hline Household & 149 & $60.1 \%$ & 64 & $25.8 \%$ & \multirow{8}{*}{.678} & \multirow{8}{*}{$\begin{array}{l}\text { Not } \\
\text { significant }\end{array}$} \\
\hline Business & 11 & $4.4 \%$ & 5 & $2.0 \%$ & & \\
\hline Labour work & 1 & $.4 \%$ & 0 & $0.0 \%$ & & \\
\hline Formal Job & 6 & $2.4 \%$ & 2 & $.8 \%$ & & \\
\hline $\begin{array}{l}\text { Foreign } \\
\text { employment/returne } \\
\text { e }\end{array}$ & 2 & $.8 \%$ & 0 & $0.0 \%$ & & \\
\hline Agriculture & 1 & $.4 \%$ & 0 & $0.0 \%$ & & \\
\hline Student & 7 & $2.8 \%$ & 0 & $0.0 \%$ & & \\
\hline Total & 177 & $71.4 \%$ & 71 & $28.6 \%$ & & \\
\hline \multicolumn{7}{|c|}{ Educational Status and postpartum depression } \\
\hline Illiterate & 24 & $9.7 \%$ & 17 & $6.9 \%$ & \multirow{3}{*}{.014} & \multirow{3}{*}{ Significant } \\
\hline Literate & 21 & $8.5 \%$ & 15 & $6.0 \%$ & & \\
\hline Primary level & 23 & $9.3 \%$ & 13 & $5.2 \%$ & & \\
\hline
\end{tabular}




\section{Original Article}

\begin{tabular}{|c|c|c|c|c|c|c|}
\hline Secondary level & 34 & $13.7 \%$ & 11 & $4.4 \%$ & & \\
\hline Higher Secondary & 44 & $17.7 \%$ & 8 & $3.2 \%$ & & \\
\hline Bachelors and above & 31 & $12.5 \%$ & 7 & $2.8 \%$ & & \\
\hline Total & 177 & $71.4 \%$ & 71 & $28.6 \%$ & & \\
\hline \multicolumn{7}{|c|}{ Main source of income and postpartum depression } \\
\hline Agricultural income & 24 & $9.7 \%$ & 11 & $4.4 \%$ & \multirow{6}{*}{.364} & \multirow{6}{*}{$\begin{array}{l}\text { not } \\
\text { significant }\end{array}$} \\
\hline $\begin{array}{ll}\text { Income } & \text { from } \\
\text { business } & \end{array}$ & 49 & $19.8 \%$ & 14 & $5.6 \%$ & & \\
\hline Income from wages & 18 & $7.3 \%$ & 12 & $4.8 \%$ & & \\
\hline Salary & 85 & $34.3 \%$ & 33 & $13.3 \%$ & & \\
\hline Animal husbandary & 1 & $.4 \%$ & 1 & $.4 \%$ & & \\
\hline Total & 177 & $71.4 \%$ & 71 & $28.6 \%$ & & \\
\hline
\end{tabular}

\begin{tabular}{|l|l|l|l|l|l|l|}
\hline \multicolumn{6}{|c|}{ Table:4 Prevalence of postpartum depression according to social factors (n = 248) } \\
\hline $\begin{array}{l}\text { N/O is months } \\
\text { income } \\
\text { sufficient for and } \\
\text { depression }\end{array}$ & Number & $\begin{array}{l}\text { \% of } \\
\text { Total }\end{array}$ & Number & $\%$ of Total & $\begin{array}{l}\text { Exact } \\
\text { Sig. (2- } \\
\text { sided) }\end{array}$ & Remarks \\
\hline 2 month or less & 60 & $24.2 \%$ & 27 & $10.9 \%$ & & \\
\hline Upto 3 months & 10 & $4.0 \%$ & 8 & $3.2 \%$ & Not \\
Upto 6 months & 10 & $4.0 \%$ & 7 & $2.8 \%$ & .115 & significant \\
\hline upto 12 months & 97 & $39.1 \%$ & 29 & $11.7 \%$ & & \\
\hline Total & $\mathbf{1 7 7}$ & $\mathbf{7 1 . 4 \%}$ & $\mathbf{7 1}$ & $\mathbf{2 8 . 6 \%}$ & & \\
\hline
\end{tabular}




\section{Original Article}

\begin{tabular}{|c|c|c|c|c|c|c|}
\hline \multicolumn{7}{|c|}{ Husband Education and postpartum depression } \\
\hline Illiterate & 7 & $2.8 \%$ & 11 & $4.4 \%$ & \multirow{7}{*}{.006} & \multirow{7}{*}{$\begin{array}{l}\text { Nearly } \\
\text { Significan }\end{array}$} \\
\hline Literate & 15 & $6.0 \%$ & 13 & $5.2 \%$ & & \\
\hline Primary level & 25 & $10.1 \%$ & 8 & $3.2 \%$ & & \\
\hline Secondary level & 41 & $16.5 \%$ & 12 & $4.8 \%$ & & \\
\hline Higher Secondary & 49 & $19.8 \%$ & 18 & $7.3 \%$ & & \\
\hline $\begin{array}{l}\text { Bachelors and } \\
\text { above }\end{array}$ & 40 & $16.1 \%$ & 9 & $3.6 \%$ & & \\
\hline Total & 177 & $71.4 \%$ & 71 & $28.6 \%$ & & \\
\hline \multicolumn{7}{|c|}{ Husband's occupation and postpartum depression } \\
\hline Household & 2 & $.8 \%$ & 0 & $0.0 \%$ & \multirow{8}{*}{.669} & \multirow{8}{*}{$\begin{array}{l}\text { Not } \\
\text { significant }\end{array}$} \\
\hline Business & 58 & $23.4 \%$ & 22 & $8.9 \%$ & & \\
\hline Labour work & 53 & $21.4 \%$ & 27 & $10.9 \%$ & & \\
\hline Formal; job & 47 & $19.0 \%$ & 20 & $8.1 \%$ & & \\
\hline Agriculture & 8 & $3.2 \%$ & 1 & $.4 \%$ & & \\
\hline Student & 1 & $.4 \%$ & 0 & $0.0 \%$ & & \\
\hline $\begin{array}{l}\text { Foreign } \\
\text { employment }\end{array}$ & 8 & $3.2 \%$ & 1 & $.4 \%$ & & \\
\hline Total & 177 & $71.4 \%$ & 71 & $28.6 \%$ & & \\
\hline \multicolumn{7}{|c|}{ Social mobility of respondent and postpartum depression } \\
\hline Alone & 114 & $46.0 \%$ & 35 & $14.1 \%$ & \multirow{5}{*}{.085} & \multirow{5}{*}{$\begin{array}{l}\text { Not } \\
\text { Significant }\end{array}$} \\
\hline $\begin{array}{l}\text { Accompanying by } \\
\text { seniors }\end{array}$ & 56 & $22.6 \%$ & 33 & $13.3 \%$ & & \\
\hline $\begin{array}{l}\text { Accompanying by } \\
\text { juniors }\end{array}$ & 5 & $2.0 \%$ & 3 & $1.2 \%$ & & \\
\hline $\begin{array}{l}\text { Accompanying by } \\
\text { husband }\end{array}$ & 2 & $.8 \%$ & 0 & $0.0 \%$ & & \\
\hline Total & 177 & $71.4 \%$ & 71 & $28.6 \%$ & & \\
\hline
\end{tabular}




\section{Original Article}

\begin{tabular}{|c|c|c|c|c|c|c|}
\hline \multicolumn{7}{|c|}{$\begin{array}{l}\text { Table:5. Prevalence of postpartum depression according to pregnancy and heath related } \\
\text { problems }(n=248)\end{array}$} \\
\hline \multirow{2}{*}{$\begin{array}{l}\text { History of any health } \\
\text { problems and postpartum } \\
\text { depression }\end{array}$} & \multicolumn{2}{|c|}{ No Depression } & \multicolumn{2}{|c|}{ Depression } & \multirow{2}{*}{$\begin{array}{l}\text { Exact } \\
\text { Sig. } \\
\text { (2- } \\
\text { sided) }\end{array}$} & \multirow[b]{2}{*}{ Remarks } \\
\hline & $\begin{array}{l}\text { Numbe } \\
\text { r }\end{array}$ & $\begin{array}{l}\text { \% of } \\
\text { Total }\end{array}$ & $\begin{array}{l}\text { Numbe } \\
\text { r }\end{array}$ & $\begin{array}{l}\text { \% of } \\
\text { Total }\end{array}$ & & \\
\hline Gastro-intestinal problem & 2 & $.8 \%$ & 1 & $.4 \%$ & \multirow{9}{*}{.143} & \multirow{9}{*}{$\begin{array}{l}\text { Not } \\
\text { significan } \\
\mathrm{t}\end{array}$} \\
\hline $\begin{array}{l}\text { Headache/shoulderache/Feve } \\
\text { r }\end{array}$ & 2 & $.8 \%$ & 3 & $1.2 \%$ & & \\
\hline Chest pain.Asthma & 1 & $.4 \%$ & 2 & $.8 \%$ & & \\
\hline Gall stone/kidney stone/stone & 3 & $1.2 \%$ & 2 & $.8 \%$ & & \\
\hline Bleeding & 0 & $0.0 \%$ & 1 & $.4 \%$ & & \\
\hline Uterine diseases/backache & 1 & $.4 \%$ & 1 & $.4 \%$ & & \\
\hline Hypertension & 1 & $.4 \%$ & 0 & $0.0 \%$ & & \\
\hline None & 167 & $67.3 \%$ & 61 & $24.6 \%$ & & \\
\hline Total & 177 & $71.4 \%$ & 71 & $28.6 \%$ & & \\
\hline \multicolumn{7}{|c|}{ Number of pregnancy and postpartum depression } \\
\hline One & 89 & $35.9 \%$ & 27 & $10.9 \%$ & \multirow{7}{*}{.195} & \multirow{7}{*}{$\begin{array}{l}\text { Not } \\
\text { significan } \\
\mathrm{t}\end{array}$} \\
\hline Two & 58 & $23.4 \%$ & 30 & $12.1 \%$ & & \\
\hline Three & 21 & $8.5 \%$ & 7 & $2.8 \%$ & & \\
\hline Four & 7 & $2.8 \%$ & 4 & $1.6 \%$ & & \\
\hline Five & 2 & $.8 \%$ & 2 & $.8 \%$ & & \\
\hline Six & 0 & $0.0 \%$ & 1 & $.4 \%$ & & \\
\hline Total & 177 & $71.4 \%$ & 71 & $28.6 \%$ & & \\
\hline
\end{tabular}




\section{Original Article}

\begin{tabular}{|c|c|c|c|c|c|c|}
\hline \multicolumn{7}{|c|}{ Number of live birth male and postpartum depression } \\
\hline One & 84 & $33.9 \%$ & 38 & $15.3 \%$ & \multirow{6}{*}{.043} & \multirow{6}{*}{$\begin{array}{l}\text { Significan } \\
\mathrm{t}\end{array}$} \\
\hline Two & 29 & \begin{tabular}{|l|}
$11.7 \%$ \\
\end{tabular} & 15 & $6.0 \%$ & & \\
\hline Three & 0 & $0.0 \%$ & 1 & $.4 \%$ & & \\
\hline Four & 0 & $0.0 \%$ & 1 & $.4 \%$ & & \\
\hline None & 64 & $25.8 \%$ & 16 & $6.5 \%$ & & \\
\hline Total & 177 & $71.4 \%$ & 71 & $28.6 \%$ & & \\
\hline \multicolumn{7}{|c|}{ Sex of the recent baby and postpartum depression } \\
\hline Male & 87 & $35.1 \%$ & 45 & $18.1 \%$ & \multirow{3}{*}{.049} & \multirow{3}{*}{$\begin{array}{l}\text { Significar } \\
\mathrm{t}\end{array}$} \\
\hline Female & 90 & $36.3 \%$ & 26 & $10.5 \%$ & & \\
\hline Total & 177 & \begin{tabular}{|l}
$71.4 \%$ \\
\end{tabular} & \begin{tabular}{|l|}
71 \\
\end{tabular} & $28.6 \%$ & & \\
\hline
\end{tabular}

Table: 6. Prevalence of depression according to place and type of delivery $(n=248)$

\begin{tabular}{|c|c|c|c|c|c|c|}
\hline \multirow{2}{*}{$\begin{array}{l}\text { Place of } \\
\text { Delivery and } \\
\text { postpartum } \\
\text { depression }\end{array}$} & \multicolumn{2}{|c|}{ No Depression } & \multicolumn{2}{|c|}{ Depression } & \multirow{2}{*}{$\begin{array}{l}\text { Exact } \\
\text { Sig. (2- } \\
\text { sided) }\end{array}$} & \multirow[b]{2}{*}{ Remarks } \\
\hline & Number & $\begin{array}{ll}\text { \% } & \text { of } \\
\text { Total } & \end{array}$ & Number & \% of Total & & \\
\hline Institutional & 165 & $66.5 \%$ & 67 & $27.0 \%$ & \multirow{3}{*}{1.000} & \multirow{3}{*}{$\begin{array}{l}\text { Not } \\
\text { significant }\end{array}$} \\
\hline Home & 12 & $4.8 \%$ & 4 & $1.6 \%$ & & \\
\hline Total & 177 & $71.4 \%$ & 71 & $28.6 \%$ & & \\
\hline \multicolumn{7}{|c|}{ Type of delivery and postpartum depression } \\
\hline $\begin{array}{l}\text { Normal } \\
\text { vaginal } \\
\text { delivery }\end{array}$ & 149 & $60.1 \%$ & 63 & $25.4 \%$ & \multirow{3}{*}{.429} & \multirow{3}{*}{$\begin{array}{l}\text { not } \\
\text { significant }\end{array}$} \\
\hline $\begin{array}{l}\text { Caesarian } \\
\text { section }\end{array}$ & 28 & $11.3 \%$ & 8 & $3.2 \%$ & & \\
\hline Total & 177 & $71.4 \%$ & 71 & $28.6 \%$ & & \\
\hline
\end{tabular}




\section{DISCUSSION}

Postpartum non-psychotic depression is the most common complication of childbearing affecting about $10-15 \%$ of women. ${ }^{6}$ Female users make up over $35 \%$ of the population in all mental health facilities in the country. The proportion of female users is highest in out patient facilities, day treatment facilities and community based psychiatric inpatient facilities, and relatively lower in the mental hospital. ${ }^{11}$

Physiological theory of depression said that it can be due to biological reason or changes in the hormone during pregnancy and lactation. ${ }^{12}$

In a study Hamilton Rating Scale of Depression (HRSD) was applied to the subjects, 9.8\% had mildly depressed, $47.1 \%$ moderate and $43.1 \%$ were severely depressed. ${ }^{13}$

A study on the neglected ' $m$ ' in MCH programmes, why mental health of mothers is important for child nutrition, found that in low-income countries, the prevalence of maternal depression is estimated at $15-25 \% .^{14}$

It was identified in this study, among 3 participants of IDI, were from 21 to 27 years of age, 2 were Brahmins and 1 was Janajati had some degree of depression.

Nepal Adolescent and Youth Survey revealed that 12\% females reported that they felt sad and depressed for several days than males $9 \%{ }^{15}$

During IDI it was found that husband of one participants had gone to foreign labour work and she had expressed her feelings as "we have fair relationship, " since he is working in the foreign country and supporting family by financially but psychological and emotional needs are not fulfilled as needed."

In a study it was mentioned that multi-parity emerged as a very significant contributing factor to the development of PPD. ${ }^{16}$ 
From the 2 FGDs, bleeding was recognized as one of the common problems during delivery, prolonged labor (2 FGD), no fetal movement (2 FGD), asphyxiated baby (1 FGD), and still birth were identified as the common problem during labor/delivery.

In the same study it was revealed that giving birth to a daughter when a son was desired can be a significant family and social stressor in Indian societies". ${ }^{16}$

The determinants of PPD in resource-rich and resource-limited settings share themes crossculturally. However, unique factors such as sex of the child, protective influence of the various traditional rituals, financial insecurity, marital violence, lack of social support have emerged as risk factors for PPD in low and medium income countries like India, Pakistan, Turkey and Nigeria. ${ }^{16}$

All three participants from IDI said that mental tension can be the main reason for post partum depression. Most of the key informants recognized that lack of family support to the women can lead to PPD.

In some studies it was revealed that a greater proportion of women in the depressed group had a poor quality of married life when compared to the non-depressed group. ${ }^{16}$

A study of Nepal reported that prevalence of depressive symptoms among postpartum women about $5 \%$ and a strong association with husband's alcoholism, polygamy and previous depression". ${ }^{17}$

The findings from FGD 1 stated that "the main cause of the PPD is family problem. " One of the participants said that "some of the women have habit of over thinking and that leads to mental health problems."

\section{CONCLUSION}

The postpartum depression is multi-factorial and is influenced by various psycho -social aspects such as family relationships, economic condition, emotional condition or physical health related issues. Since it is multi-factorial then interventions should also be multi-sectorial. 
It was found that people visited traditional healers as well as modern health facilities while they have mental health problems. To generalize the findings in larger population it is better to conduct country level large scale research studies on PPD and other psychosocial problems of women.

\section{REFERENCES}

1. WHO. Constitution of World Health Organization: Principles. World Health Organization, Geneva, Switzerland, 1948. Available on:

http://www.who.int/governance/eb/who_constitution_en.pdf

2. WHO. Concept of mental health. World Health Organization, Geneva, Switzerland. (2010). Available link: http://www.who.int/mental_health/evidence/en/promoting_mhh.pdf

3. WMHD. Depression: A global crisis. 20 ${ }^{\text {th }}$ Anniversary of World Mental Health Day October 10, 2012. World Federation for Mental Health. PO Box 807 Occoquan, VA 22125, USA. Available on:

http://www.who.int/mental_health/management/depression/wfmh_paper_depression_wm hd_2012.pdf

4. KOSHIS Nepal. Mental Health in Nepal: The Voices of Koshish. Koshish Nepal. 2010. Available link http://www.apa.org/international/pi/2011/07/nepal.aspx

5. WHO. World Health Report. Available on: http://apps.who.int/iris/bitstream/handle/10665/44844/9789241564441_eng.pdf;jsessioni $\mathrm{d}=\mathrm{C} 19 F 1685736022 B 868 A 90 B A 127 C 97 E D 1$ ?sequence=1 World Health Organization, Geneva, Switzerland.2012.

6. Donna E Stewart, Emma Robertson,Cindy-Lee Dennis, and Sherry Grace. Postpartum Depression: Literature Review of Risk Factors and Interventions. Available on: https://www.ncbi.nlm.nih.gov/pmc/articles/PMC1414677/ University Health Network Women’s Health Program 2003. Toronto Public Health. Ontario. Canada.

7. O'Hara MW, Neunaber DJ, Zekoski EM.. Prospective study of postpartum depression: Prevalence, course, and predictive factors. Journal of Abnormal Psychology, Vol 93(2), May 1984, 158-171. Available on: https://www.ncbi.nlm.nih.gov/pubmed/6725749

8. Registered Nurses' Association of Ontario. Interventions for Post Partum Depression: Nursing Best Practice Guidelines. Toronto, Canada: Registered Nurses' Association of Ontario. 2005. Available on: https://rnao.ca/sites/rnaoca/files/Interventions_for_Postpartum_Depression.pdf

9. NDHS. Postnatal care for the mother. Nepal Demographic and Health Survey key indicators preliminary report 2016. Ministry of Health and New Era, Kathmandu Nepal.2016. available on: https://www.dhsprogram.com/pubs/pdf/fr336/fr336.pdf 
10. Cox JL, Holden JM, Sagovsky R. Detection of postnatal depression: development of the 10-item Edinburgh Postnatal Depression Scale. Br J Psychiatry. 1987; (Available on https://www.ncbi.nlm.nih.gov/pubmed/3651732)150:782-786

11. WHO-AIMS Report on Mental Health System in Nepal, WHO and Ministry of Health, Kathmandu, Nepal, 2006.

12. Abdollahi F, Lye MS, Zarghami M .Perspective of Postpartum Depression Theories: A Narrative Literature Review. N Am J Med Sci. 2016 Jun;8(6):232-6. doi: 10.4103/19472714.185027. Available on https://www.ncbi.nlm.nih.gov/pubmed/27500126

13. Ather Muneer, Fareed Aslam Minhas, Asad Tamiz-ud-Din Nizami, Faiza Mujeeb, Asma Tanvir Usmani. Frequency and Associated Factors for Postnatal Depression. Rawalpindi, Pakistan: Rawalpindi General Hospital. 2008. Available on: https://jcpsp.pk/archive/2009/Apr2009/09.pdf

14. Atif Rahman, Vikram Patel Joanna Maselko Betty Kirkwood.The Neglected 'm' in MCH Programmes - Why Mental Health of Mothers is Important for Child Nutrition? Tropical Medicine and International Health. 2008, 13 (4): 579-583. doi: 10.1111/j.13653156.2008.02036.x

15. MOHP/Population Division. Mental Health Status. Report of Nepal Adolescent and Youth Survey, 2068. Kathmandu: MOHP/Population Division. 2012. (74-75).

16. Hegde S, Latha KS, Bhat SM , Sharma PSVN, Kamath A, et al. Postpartum Depression: Prevalence and Associated Factors among Women in India. Journal of Women's Health, Issues Care 2012, 1:1. doi: 10.4172/2325-9795.1000101

17. Budhathoki N, Dahal M, Bhusal S, Ojha H, Pandey S, Basnet S. Violence against Women by their Husband and Postpartum Depression. Journal of Nepal Health Research Council, 2012. 10 (22): 176-80. 